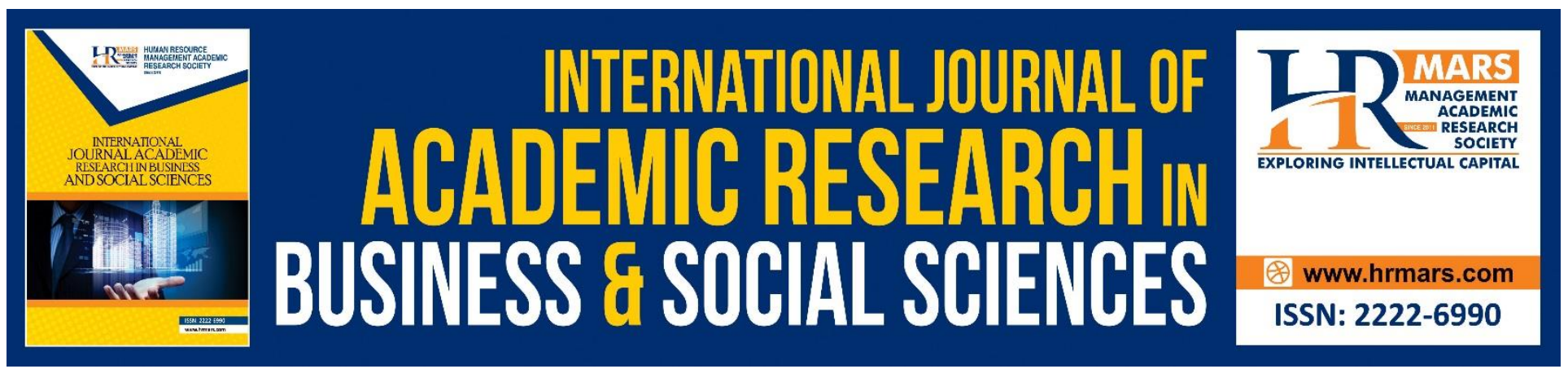

\title{
The Element of Teaching Strategy in English Listening Skills for Preschool: Fuzzy Delphi Technique Approach
}

Norshimar Akmar Hashim, Mazlina Che Mustafa, Azli Ariffin, Zarina Eshak

To Link this Article: http://dx.doi.org/10.6007/IJARBSS/v10-i7/7612

DOI:10.6007/IJARBSS/v10-i7/7612

Received: 17 April 2020, Revised: 22 May 2020, Accepted: 09 June 2020

Published Online: 18 July 2020

In-Text Citation: (Hashim et al., 2020)

To Cite this Article: Hashim, N. A., Mustafa, M. C., Ariffin, A., \& Eshak, Z. (2020). The Element of Teaching Strategy in English Listening Skills for Preschool: Fuzzy Delphi Technique Approach. International Journal of Academic Research in Business and Social Sciences, 10(7), 818-830.

Copyright: (c) 2020 The Author(s)

Published by Human Resource Management Academic Research Society (www.hrmars.com)

This article is published under the Creative Commons Attribution (CC BY 4.0) license. Anyone may reproduce, distribute, translate and create derivative works of this article (for both commercial and non-commercial purposes), subject to full attribution to the original publication and authors. The full terms of this license may be seen

at: http://creativecommons.org/licences/by/4.0/legalcode

Vol. 10, No. 7, 2020, Pg. 818 - 830

http://hrmars.com/index.php/pages/detail/IJARBSS

JOURNAL HOMEPAGE

Full Terms \& Conditions of access and use can be found at http://hrmars.com/index.php/pages/detail/publication-ethics 


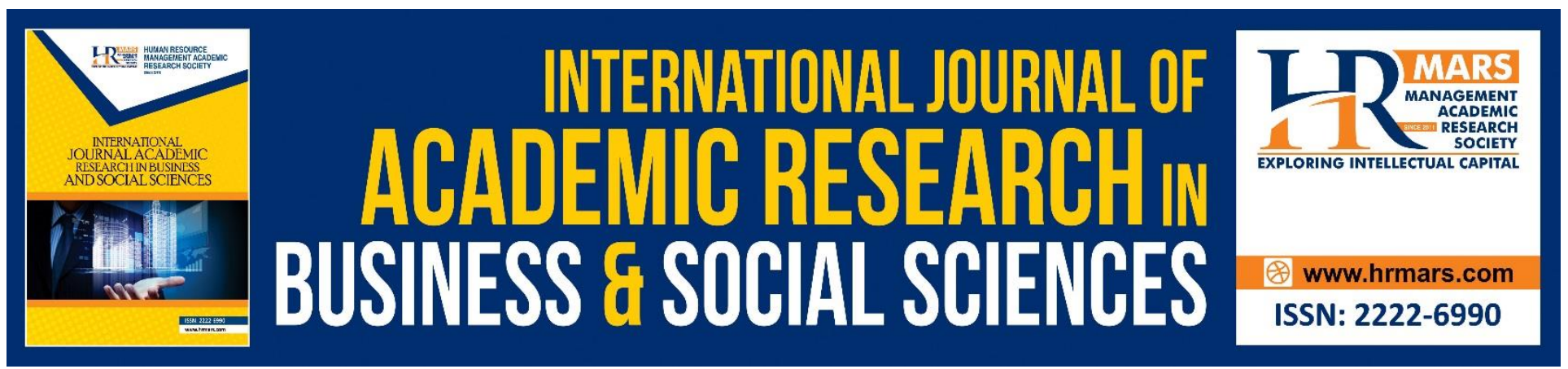

\title{
The Element of Teaching Strategy in English Listening Skills for Preschool: Fuzzy Delphi Technique Approach
}

\section{Norshimar Akmar Hashim, Mazlina Che Mustafa, Azli Ariffin, Zarina Eshak}

Human Development Faculty, Sultan Idris Education University, 35900 Tanjong Malim, Perak. Malaysia.

Email: norshimar@gmail.com, mazlina.cm@fpm.upsi.edu.my, azli@fpm.upsi.edu.my, zarinaeshak79@gmail.com

\begin{abstract}
This article reviews the use of Fuzzy Delphi in determining the elements of a preschool English listening skill teaching strategy. The choice of these elements can be seen as a process of decision making by experts from early childhood education and English curriculum specialists. This study aims to provide a systematic approach to element selection and element sequencing, in which there are two phases of the procedure. The first stage uses the Fuzzy Delphi Method to obtain expert consensus on the elements and second, to identify the sequences of each element. The results showed that five elements were accepted for the English listening skills teaching strategy with 15 experts as a sample. It meets the threshold value of less than 0.2 , and the percentage of expert groups is over $75 \%$. This finding indicates that all of the elements are necessary to develop a preschool listening teaching strategy based on expert consensus.
\end{abstract}

Keywords: Elements of Teaching Strategy, Listening Skills, Fuzzy Delphi, Preschool, English Language.

\section{Introduction}

Language development starts since a child is born and develops with direct experiences, upbringing, education, and encouragement given by the adults around them. This fact has been discussed by prominent researchers and experts in early childhood education, such as (Beaty \& Pratt, 2011; Chomsky \& Smith, 2000; Arshad, 2012; Piaget, 1959). Chomsky \& Smith (2000) stated that children's existing language processing tools in the brain is called the Language Acquisition Devise (LAD). The LAD can process words they hear and be able to repeat the pronunciation of the word. It is to be used at the appropriate time based on their experiences (Muchau, 2015).

The development of children's language involves the ability to listen, speaking, reading, and writing. Listening, speaking, reading and writing are part of communication which begin with hearing and responding to sounds. Children begin communicating and developing language on the day they 
were born (Anderson et al., 2010). As children grow and develop, they start listening for different purposes and responding with words instead of sounds and gestures. As Baker, Mogna, Rodriguez, Farmer, and Yovanoff (2016) discussed that communication is receptive language (listening), which anticipate speaking skill. Listening and speaking skills lay the foundation for future success in reading and writing (Baker et al., 2016). These skills develop children's opportunities to listen to and talk with their parents, relatives, friends, and caregivers (Mullen, 2017).

Apart from that, children's ability to use English as a second language and as an interaction tool in daily life becomes one of the Preschool Curriculum's objectives (Ministry of Education, 2017). The curriculum component aims to ensure that children can listen actively through meaningful interactions with suitable language activities in the respective language.

The Fuzzy Delphi method is a widely accepted approach and widely used in collecting data for a study based on the consensus of a group of experts on a given issue (Hsu \& Ohio, 2007). The clout of the Fuzzy Delphi method has also resulted in various techniques for obtaining empirical data, such as the Fuzzy Delphi (FDM) method. Discussing the Fuzzy Delphi (FDM) method, it is a method of measurement that is modified based on the Delphi method. This method was introduced by Kaufmann \& Madan M Gupta in 1988. This Fuzzy Delphi (FDM) method is a combination of the fuzzy numbering set and the Delphi method itself (Murray et al., 1985). It implies that it is not a new approach. It also based on the classic Delphi method whereby the respondents involved must be among the experts experienced in the field of study. These improvements have indirectly enabled the Fuzzy Delphi (FDM) method to be a more useful measurement approach whereby it has been able to solve problems of uncertainty for a given issue. Previous literature shows that the Fuzzy Delphi method (FDM) is a combination of the traditional (classical) Delphi method and the fuzzy set theory. A mathematician introduced this fuzzy set theory in 1965 called Lotfi Zadeh (Zadeh, 1965), and it works as a continuation of the classical set theory where each element in a set is evaluated based on a binary set (Yes or No). The fuzzy set theory also allows for a continuous assessment of each element studied. Ragin (2007) states that the value of fuzzy numbering ranges from 0 to 1 or in-unit intervals $(0,1)$.

\section{Research Question}

The following research questions have been proposed as the basis for this study:

a) What are the elements of the listening skills teaching strategy?

b) What are the priority elements of the listening skill teaching strategy?

\section{Theory}

The theoretical framework of this study is the result of the literature review on teaching strategies for listening skills, models, and theories related to the study. The theoretical framework for this study is a combination of theories and models: the theory underlying this study is the social-cultural theory, second language acquisition theory, multiple intelligent theory, teaching SIM model, and direct instruction model.

The essential concept in the Socio-Cultural Theory (Vygotsky, 1986) is that he believes that children's language, cognitive, and social capabilities can be enhanced through social support and interaction. Vygotsky states that the learning experienced by children only functions when they interact with people around them, and when they perform collaboration with their peers (Deshmukh et al., 2019). According to Vygotsky (1986), children's intelligence will determine just how fast they 
can catch up on the concept and function of meaningful words that they are listening to the stimulus. With a sufficient amount of vocabulary, listen from the teacher will prepare the children to speak well (Hamouda, 2013).

Other than the vital concept introduced by Vygotsky (1986) is the zone of proximal development or ZPD. ZPD represents the tasks that are not able to be done by children alone, but children will be able to do it with the help of teachers. The advice or better known as scaffolding, is the support given to children in the learning process until they can be independent with the knowledge or skills that they have mastered.

Besides, there is a combination of two more theories, which are second language acquisition theory and multiple intelligent theory. Second language theories are to guide teachers teaching the English language as a second language in a suitable way, depending on the children's age. Listening skill is the skill that has to actively done by the teacher for them to speak English naturally. Krashen (1981) said that children need to work hard to acquire a second language after puberty. It is not just about learning it as a way to improve speaking and interacting skills using that language, and it starts from listening. Multiple Intelligence theories are useful in this study opened up many new dimensions of human intelligence. The Multiple intelligence theory forms the basis for developing a model of teaching strategies to create more productive teaching and early childhood education curriculum in Malaysia (Curriculum Development Division, 2017; Curriculum Development Division, 2018). The teaching strategies designed to meet the Development Appropriate Practice (DAP), common sense, interests, and interests of children, although the teaching focus of the study was English listening skills (National Association for the Education of Young Children, 2009).

The model of the Direct instruction model (Gersten et al., 1986) provides a useful account of how vital listening skills in interaction. In this model, students can ask more questions and request assistance impact of listening skills. They can also discuss their interests so that the teacher to add those to the lessons. Other than that, it emphasizes the building of appropriate relationships. Moreover, direct instruction helps facilitate listening, which encourages more classroom contact. Students get a better chance to express their thoughts and emotions in a group (Gu, 2015). They can get to know one another as well as their teachers. Moving to direct instruction has been very successful at school. It can prepare the students for their academic future while addressing their individual needs. This change has allowed teachers to give students the means to be more successful in the future. A recent study has shown that there is an interaction between learning strategies and achievement motivation toward cognitive learning outcomes (Buchori et al., 2017). It is mean that interaction can have a positive impact on the students' performance.

The last model that the researcher used in this study is the Teaching Model Sim. The model explains about the teaching process takes place through the interaction of several components, namely teacher, children, content, objective, and environment (Ahmad, 1989). The model built on the concept of teaching as a field of communication. The interaction between teachers and students with the objectives and content of a particular environment. Based on this model, the objectives and content of the lesson should be determined exploratively, and according to children's abilities. The Sim Model emphasizes the positive relationship between teachers and children to create healthy interactions, and effective teaching and learning environments start from listening skills. 
INTERNATIONAL JOURNAL OF ACADEMIC RESEARCH IN BUSINESS AND SOCIAL SCIENCES Vol. 10, No. 7, July, 2020, E-ISSN: 2222-6990 @ 2020 HRMARS

\section{Theoretical Framework}

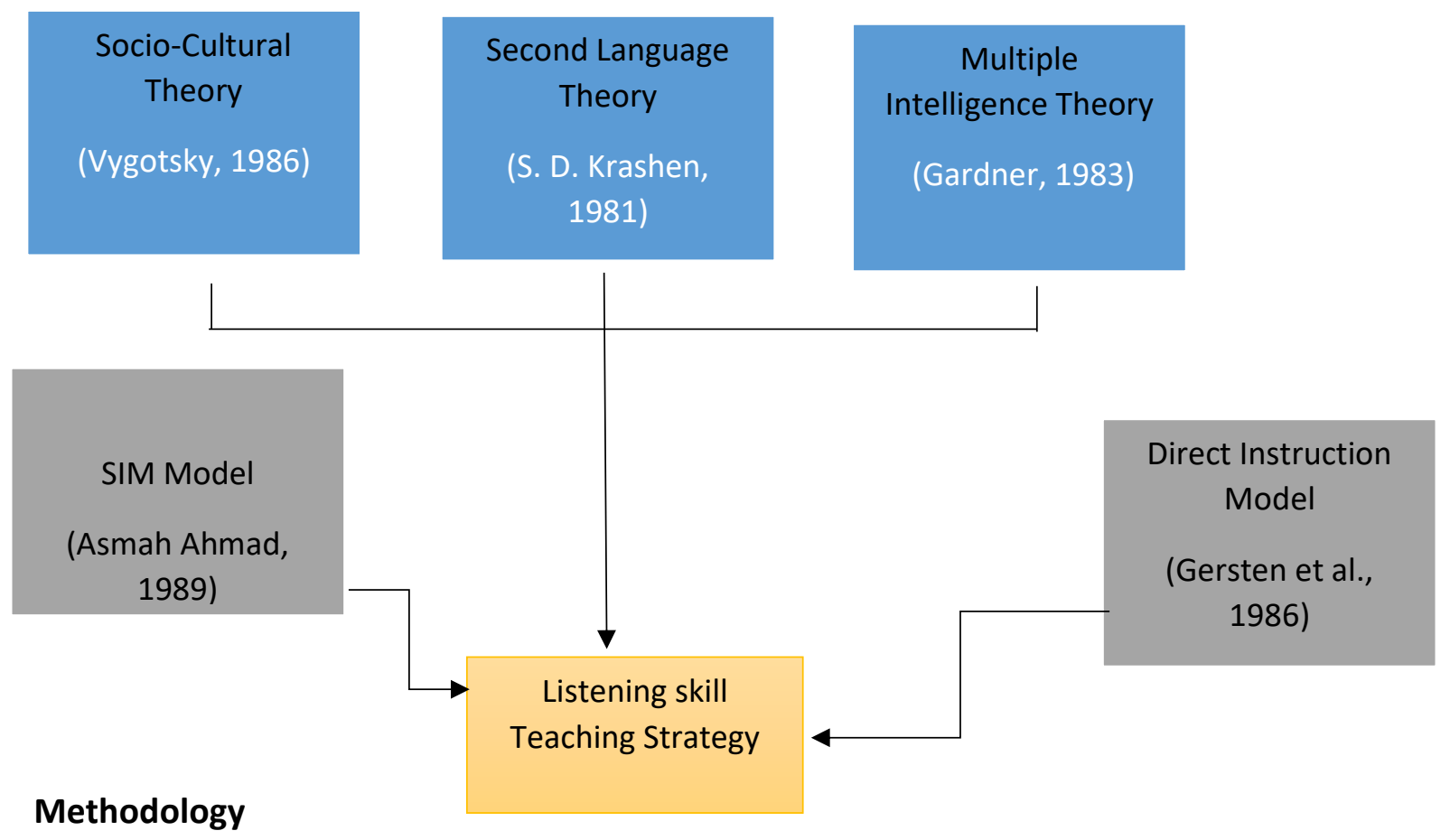

This study is a quantitative study that applied the Fuzzy Delphi Technique to gain expert consensus on the essential elements of listening skills teaching strategies and to identify the position of each item based on expert consensus. Also, this study conducted to determine elements of the teaching strategies for listening skills to be used by teachers to plan to teach. This method involves the use of fuzzy set theory, which incorporated into the classical Delphi method, where the Likert scale chosen by the expert will be converted to the fuzzy scale using fuzzy numbering consisting of binary terms $(0,1)$. This fuzzy numbering integration will produce three values, namely the minimum value, the most reasonable value, and the maximum value to be chosen by the expert.

\section{Sampling}

In this study, the researchers selected expert panel respondents consisting of 15 expert panels for FDM. There are 10 Early Childhood Education specialists and 5 English Language Education specialists based on Table 1. 
INTERNATIONAL JOURNAL OF ACADEMIC RESEARCH IN BUSINESS AND SOCIAL SCIENCES Vol. 10, No. 7, July, 2020, E-ISSN: 2222-6990 @ 2020 HRMARS

Table 1: Expert criteria for FDM

\begin{tabular}{llccccccc}
\hline No & Expert & & \multicolumn{2}{c}{ Level of education } & \multicolumn{2}{c}{ Gender } & Total \\
\hline $\mathbf{1}$ & Dip & Degree & Master & PhD & Man & Female & sample \\
\hline $\begin{array}{l}\text { Early } \\
\text { childhood } \\
\text { education }\end{array}$ & 1 & 2 & 5 & 2 & 2 & 8 & 10 \\
\hline $\mathbf{2}$ & $\begin{array}{l}\text { English } \\
\text { Language }\end{array}$ & 0 & 2 & 2 & 1 & 0 & 5 & 5 \\
\hline & Total & & & & & & 15 \\
\hline
\end{tabular}

Based on the argument by Berliner (2004), he points out that lecturers or teachers who have served for five to ten years categorized as experts in which they practice teaching and administrative management regularly. In the first part, the researcher uses the Fuzzy Delphi Method, and the most important thing is the selection of experts. According to Dalkey (1972), experts in the Delphi method are knowledgeable and skilled in a particular field. Therefore, in the Fuzzy Delphi method, the total number of experts in a given study is 15 respondents. It is in line with (Jones \& Twiss, 1978), who gave the number of experts in the Delphi study of 10 to 50 experts. However, there is also an opinion stating that a minimum number of experts for the Delphi technique is a total of five experts (Rosnaini, 2006). It corresponds with the argument Rowe \& Wright (2001) that the number of experts may begin from 5 to 20 people based on their areas of expertise. Adler \& Ziglio (1996) further suggest that the number of experts involved in the Delphi method is from 10 to 15 experts in case of a high degree of agreement and uniformity of experts.

\section{Instrument}

There are three intermediates used in this study. First, the researcher had an interview with a field specialist. These interview questions based on the chosen model and the literature review. Second, a list of elements needed in the development of model content in preschool. This list derived from the literature review and interviews with experts during the implementation of the first step in the second phase of the FDM session. It used the Fuzzy Delphi technique. The findings from the second phase used to design English language listening skills teaching strategies in preschool. This list serves as a guide for experts to identify which elements of the model are most appropriate and inclusion in the content of the model to be formed. All of these elements need expert agreement and consensus on whether they can be incorporated into the model or wholly rejected. Experts are also allowed to add other elements that they think are appropriate for inclusion in the model. The final list of elements selected and agreed is presented in a questionnaire to the expert. Experts are required to answer the FDM questionnaire on each of the selected elements to determine its position and importance (Ahmad, 2018; Ariffin, 2017; Jamil, 2016; Yusof, 2019). The Fuzzy Delphi technique was used in the second phase because it was the best way to obtain expert consent in identifying the elements that could be included in the design of the English language listening skills teaching strategy for preschool.

Questionnaires are used as instruments to obtain quantitative data on teaching strategies for English language listening skills in preschool. The use of the questionnaire is to meet the criteria and conditions of using the Fuzzy Delphi technique, which involves the use of mathematical formulas to obtain expert consensus. The instrument used by the researcher is a modified instrument based on the research needs. 
INTERNATIONAL JOURNAL OF ACADEMIC RESEARCH IN BUSINESS AND SOCIAL SCIENCES

Vol. 10, No. 7, July, 2020, E-ISSN: 2222-6990 @ 2020 HRMARS

This study uses quantitative data; according to Hua (2016), the selection of appropriate statistical tests should take into account the type of data scale, sample size, measurement, and data type (parametric and non-parametric). All data will be processed using the Fuzzy Delphi Method (FDM).

\section{Data Processing}

The Fuzzy Delphi Technique will process the data obtained from the research question set. In applying the Fuzzy Delphi technique to a study, there are steps to be followed for this study to be considered empirical research. The steps to follow are as follows:

Step 1

Set questions for the Fuzzy Delphi questionnaire based on the following:

i. Literature review

ii. Expert interview

iii. Focus group

The process of developing a questionnaire script is similar to the development of a standard questionnaire. The Likert Scale will be used in the survey. It will be based on the needs of the research questions. It required to be measured by the researcher, such as consent, level, and importance.

\section{Step 2}

The assumption that expert $\mathrm{X}$ invited to determine the significance of the evaluation criteria for the variables to be measured using linguistic variables. In this step, the process of obtaining data and information from experts depends on the researcher's initiative. Among the possible methods are as follows:

i. $\quad$ Conduct scientific seminars or workshops and invite experts to participate

ii. Meet face to face with each expert

iii. Online dissemination is like an email to a well-known expert in the field of study.

iv. Virtual meeting platform

\section{Step 3}

Converts to all linguistic variables into a fuzzy triangular numbering. Assume that fuzzy numbers are variables for each criterion for expert $X$ for $i=1, \ldots . ., m, j=1, \ldots . . n, k=1 \ldots . ., k$ and $r i j=1 / X(r 1 i j \pm$ $r 2 \mathrm{ij} \pm \mathrm{rXij}$ ). The table shows the fuzzy scale, which includes the linguistic variables showing for the five scales in the fuzzy Delphi method. 
INTERNATIONAL JOURNAL OF ACADEMIC RESEARCH IN BUSINESS AND SOCIAL SCIENCES

Vol. 10, No. 7, July, 2020, E-ISSN: 2222-6990 @ 2020 HRMARS

Table 2: Level of Agreement and Fuzzy Scale for 7 points

\begin{tabular}{ll}
\hline Linguistic Variables & Fuzzy scales \\
\hline Extremely disagree & $(0.0,0.0,0.1)$ \\
Strongly disagree & $(0.0,0.1,0.3)$ \\
Disagree & $(0.1,0.3,0.5)$ \\
Not sure & $(0.3,0.5,0.7)$ \\
Agree & $(0.5,0.7,0.9)$ \\
Strongly agree & $(0.7,0.9,1.0)$ \\
Extremely agree & $(0.9,1.0,1.0)$ \\
\hline
\end{tabular}

There are also linguistic variables that are adapted to the needs of the study objectives and questions. For example: 'EXTREMELY DISAGREE' and 'EXTREMELY AGREE.' For linguistic variables, this is often used to look at comparisons of items in a study.

\section{Step 4}

Once the researcher has successfully obtained all the data and information from the expert, the researcher should convert all Likert scales to fuzzy scales. All this data and information will be analyzed using Microsoft Excel software.

For each expert, use the vertex method to calculate the distance between the average rims (Chen, 2000). The ranges of two fuzzy numbers $m=(m 1, m 2, m 3)$ and $n=(m 1, m 2, m 3)$ calculated using the following formula:

$$
d(\tilde{m}, \tilde{n})=\sqrt{\frac{1}{3}\left[\left(m_{1}-n_{1}\right)^{2}+\left(m_{2}-n_{2}\right)^{2}+\left(m_{3}-n_{3}\right)^{2}\right]} .
$$

\section{Step 5}

According to Cheng and Lin, 2002, if the distance between the average and the expert evaluation data was less than the threshold value of 0.2 , then all experts considered consensus. Besides, among experts, if the percent reached the agreement of the group is higher than 75\% (Chu \& Hwang, 2008; Murray \& Hammons, 1995), then go to step 5. If data found, a second round of the Fuzzy Delphi Method should perform or the item discarded.

Step 6

Aggregate fuzzy ratings:

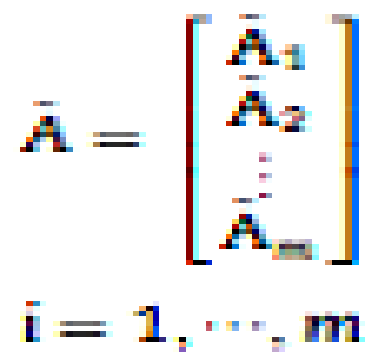


INTERNATIONAL JOURNAL OF ACADEMIC RESEARCH IN BUSINESS AND SOCIAL SCIENCES

Vol. 10, No. 7, July, 2020, E-ISSN: 2222-6990 @ 2020 HRMARS

\section{Step 7}

For each alternative choice, fuzzy evaluation of $A i=(m 1, m 2, m 3)$ in defuzzification with $A=1 / 3 *$ $(m 1+m 2+m 3)$. Alternatives to ranking options can be determined based on this value.

\section{Finding and Discussion}

Table 3 shows the results for the elements of the teaching strategy listening skills in English. This data consists of the threshold value of each element, the constructive threshold value ( $d$ construct), and the position of the element based on the expert's agreement.

Table 3: The threshold (d) value of listening skills elements

Elements

\begin{tabular}{llllll}
\hline & 1 & 2 & 3 & 4 & 5 \\
& & & & \\
1 & 0.1 & 0.0 & 0.1 & 0.3 & 0.3 \\
2 & 0.0 & 0.0 & 0.0 & 0.0 & 0.0 \\
3 & 0.0 & 0.0 & 0.0 & 0.0 & 0.0 \\
4 & 0.0 & 0.1 & 0.0 & 0.0 & 0.0 \\
5 & 0.0 & 0.0 & 0.0 & 0.0 & 0.0 \\
6 & 0.0 & 0.0 & 0.0 & 0.0 & 0.0 \\
7 & 0.0 & 0.0 & 0.1 & 0.0 & 0.0 \\
8 & 0.0 & 0.1 & 0.1 & 0.0 & 0.0 \\
9 & 0.3 & 0.0 & 0.1 & 0.0 & 0.0 \\
10 & 0.1 & 0.0 & 0.0 & 0.0 & 0.0 \\
11 & 0.0 & 0.0 & 0.0 & 0.0 & 0.0 \\
12 & 0.0 & 0.0 & 0.0 & 0.0 & 0.0 \\
13 & 0.0 & 0.0 & 0.0 & 0.0 & 0.0 \\
14 & 0.0 & 0.0 & 0.0 & 0.0 & 0.0 \\
15 & 0.0 & 0.0 & 0.0 & 0.0 & 0.0 \\
\hline Threshold value (d) & 0.065 & 0.064 & 0.062 & 0.044 & 0.042 \\
\hline Expert's agreement & & & & & \\
Percentage (\%) & $100 \%$ & $100 \%$ & $100 \%$ & $100 \%$ & $100 \%$ \\
\hline & & & & & \\
\hline Fuzzy score (A) & 0.942 & 0.940 & 0.938 & 0.930 & 0.929 \\
\hline
\end{tabular}

Based on Table 3, it shows that the whole item in the elements of the English language teaching strategy was agreed upon by a group of experts based on the criteria set out in the Delphi Fuzzy Technique analysis. Threshold constructor value ( $d$ construct $) \leq 0.2$ and expert group agreement $\geq 75 \%$. Table 4 shows the fuzzy score values that have been ranked based on expert consensus. 
INTERNATIONAL JOURNAL OF ACADEMIC RESEARCH IN BUSINESS AND SOCIAL SCIENCES Vol. 10, No. 7, July, 2020, E-ISSN: 2222-6990 @ 2020 HRMARS

\section{Table 4: Result Ranking for the elements using FDM}

\begin{tabular}{llcc}
\hline Item & \multicolumn{1}{c}{ Listening teaching strategy elements } & Fuzzy score & Ranking \\
\hline $\mathbf{2 3}$ & $\begin{array}{l}\text { Teachers' clear voice is significant to engage children's attention } \\
\text { in listening to what their teachers are saying. }\end{array}$ & 0.942 & 1 \\
\hline $\mathbf{2 6}$ & $\begin{array}{l}\text { Teachers praise children when they listen to diligently. } \\
\mathbf{1 8}\end{array}$ & $\begin{array}{l}\text { Teachers make English teaching activities fun and exciting that } \\
\text { can create a conducive learning environment. }\end{array}$ & 0.941 \\
\hline $\mathbf{1 4}$ & $\begin{array}{l}\text { Teachers use hand signals, facial expressions, and body language } \\
\text { to understand what is being conveyed. }\end{array}$ & 0.938 & 3 \\
\hline $\mathbf{2 1}$ & $\begin{array}{l}\text { Teachers use English register that is easily understood by } \\
\text { children. }\end{array}$ & 0.929 & 5 \\
\hline
\end{tabular}

\section{Discussion}

This study had the primary purpose of determining the expert's agreement on the elements of teaching listening skills in the English language. Listening skills are chosen because their teaching strategies are essential for teachers to practice proper teaching process techniques. The findings show that all of these elements agreed upon by the experts. These elements are needed for teachers to design effective teaching strategies to teach their students effectively.

Item teachers' clear voice is significant to engage children's attention in listening to what their teachers are saying become the priority. It shows that the sound of the teacher plays the most crucial role for the child to listen to what the teacher says. The clarity and volume of the teacher's voice will also determine whether the student will pay attention to what he or she is listening to (Reigado \& Rodrigues, 2018).

Second place is element teachers make the English teaching activities fun and exciting that can create a conducive learning environment. When teachers use activities that make learning engaging and fun, children are more willing to participate and take risks. At the same time, teaching and learning also help children retain information better because the process is enjoyable and memorable.

Third place is element teachers make English teaching activities fun and exciting that can create a conducive learning environment. When teachers use activities that make learning engaging and fun, children are more willing to participate and take risks. Having fun while teaching and learning also helps children retain information better because the process is enjoyable and memorable. (Chang et al., 2019).

Fourth place is element teachers use hand signals, facial expressions, and body language to understand what is being conveyed. To make it simpler for the children to understand what the teacher is saying during the lesson without having to translate the words one by one.

Fifth place is element teachers use English register that is easily understood by children. The teacher should use suitable English language adjustments for children should be used depending on the age of the preschool child (Oddo, 2015).

\section{Conclusion}

Teachers play a vital part in making sure English listening skill is fully developed by children before speaking, writing, and reading skills. Listening skills are an essential skill for children to master the art of speaking. Therefore, appropriate teaching strategies are essential for improving children's English listening skills. A strong coalition of these five elements will respond to the call of the Ministry of 
INTERNATIONAL JOURNAL OF ACADEMIC RESEARCH IN BUSINESS AND SOCIAL SCIENCES

Vol. 10, No. 7, July, 2020, E-ISSN: 2222-6990 @ 2020 HRMARS

Education to produce globally competitive students (Ministry of Education, 2013). Therefore, the existence of the elements of this English listening skill teaching strategy expected to give a new dimension to preschool education, especially in the field of English language education.

\section{References}

Ahmad, A. M. (2018). Pembangunan Model ENi Berasaskan Aktiviti Inkuiri bagi Program Latihan Kemahiran Kejuruteraan Institut Latihan Kemahiran Malaysia. Universiti Malaya.

Adler, M., \& Ziglio, E. (1996). Gazing into Oracle: Delphi method and its Application to Social Policy and Public Health. Jessica Kingsley Publisher.

Anderson, S., Baker, C. A., Leavitt, B., Mclaughlin, A., \& Robinson, T. (2010). Rhymers Are Readers: The Importance of Nursery Rhymes KBYU Eleven Ready To Learn ${ }^{\circledR}$. http://kbyutv.org/kidsandfamily/readytolearn/file.axd?file=2011\%2F3\%2F2+Rhymers+are+Rea ders.pdf

Ahmad, A. H. (1989). Pedagogi 1. Siri Pendidikan Longman.

Ariffin, A. (2017). Reka Bentuk Model Aktiviti Penggunaan Lagu Kanak-kanak Melayu Tradisioanal untuk Peningkatan Imaginasi-Krewatif Prasekolah. University of Malaya.

Arshad, M. (2012). Pendidikan literasi awal kanak-kanak: teori dan amali. Penerbit Universiti Pendidikan Sultan Idris.

Baker, D. L., Mogna, V., Rodriguez, S., Farmer, D., \& Yovanoff, P. (2016). Building the Oral Language of Young Hispanic Children Through Interactive Read Alouds and Vocabulary Games at Preschool and at Home. Journal of International Special Needs Education.

Beaty, J. J., \& Pratt, L. (2011). Children's Speaking/Listening.

Berliner, D. C. (2004). Expert Teachers : Their Characteristics, . DE LA TEORIA... A L'AULA.

Buchori, A., Setyosari, P., Dasna, I. W., Ulfa, S., Degeng, I. N. S., \& Sa, C. (2017). Effectiveness of Direct Instruction Learning Strategy Assisted by Mobile Augmented Reality and Achievement Motivation on Students Cognitive Learning Results. Asian Social Science, 13(9), 137-144. https://doi.org/10.5539/ass.v13n9p137

Chang, A., Millett, S., \& Renandya, W. A. (2019). Developing Listening Fluency through Supported Extensive Listening Practice. RELC Journal, 50(3), 422-438.

https://doi.org/10.1177/0033688217751468

Chen, C. (2000). Extensions of the TOPSIS for group decision making under Fuzzy Environment. In Fuzzy Sets and System 114 (pp. 1-9).

Chomsky, N., \& Smith, N. (2000). New Horizons in the Study of Language and Mind. New Horizons in the Study of Language and Mind. https://doi.org/10.1017/cbo9780511811937

Chu, H., \& Hwang, G. (2008). A Delphi-based approach to developing expert systems with the cooperation of multip[le experts. In Experts Systems with Applications (34:28, pp. 26-40).

Curriculum Development Division. (2017). National Preschool Standard-Based Curriculum. Ministry of Education.

Curriculum Development Division. (2018). KSPK English Language Teacher's Kit. Ministry of Education.

Dalkey, N. (1972). The Delphi Method: An Experimental Study of Group Opinion. In N.C.

Deshmukh, R. S., Zucker, T. A., Tambyraja, S. R., Pentimonti, J. M., Bowles, R. P., \& Justice, L. M. (2019). Teachers' use of questions during shared book reading: Relations to child responses. Early Childhood Research Quarterly, 49, 59-68. https://doi.org/10.1016/j.ecresq.2019.05.006 
INTERNATIONAL JOURNAL OF ACADEMIC RESEARCH IN BUSINESS AND SOCIAL SCIENCES Vol. 10, No. 7, July, 2020, E-ISSN: 2222-6990 @ 2020 HRMARS

Gardner, H. (1983). Howard Gardner's Theory of Multiple Intelligences Verbal-Linguistic Intelligence Mathematical-Logical Intelligence Visual-Spatial Intelligence.

Gersten, R., Woodward, J., \& Darch, C. (1986). Direct Instruction: A Research-Based Approach to Curriculum Design and Teaching. Exceptional Children, 53(1), 17-31. https://doi.org/10.1177/001440298605300102

Gu, L. (2015). Language ability of young English language learners: Definition, configuration, and implications. Language Testing. https://doi.org/10.1177/0265532214542670.

Hamouda, A. (2013). An Investigation of Listening Comprehension Problems Encountered by Saudi Students in the EL Listening Classroom. HR Mars, 2(2), 113-155.

Hsu, C., \& Ohio, T. (2007). The Delphi Technique : 12(10).

Hua, A. K. (2016). Pengenalan Rangkakerja Metodologi dalam Kajian Penyelidikan : Satu Kajian Kes. Journal of Social Sciences and Humanities, 1(May), 17-23. https://doi.org/10.6084/M9.FIGSHARE.3362656

Jones, H., \& Twiss, B. L. (1978). Forecasting Technology for Planning Decisions. Mac Millan.

Kaufmann, A., \& Gupta, M. M. (1988). Fuzzy mathematical models in engineering and management science. Amsterdam; New York : North-Holland ; New York, N.Y., U.S.A. : Sole distributors for the U.S.A. and Canada, Elsevier Science Pub. Co.

Krashen, S. D. (1981). Second Language Acquisition and Second Language Learning (First Edit). Newbury House, the Center for Applied Linguistics, Language Learning, TESOL, the SPEAQ Journal, Academic Press. https://doi.org/10.1111/j.1467-9922.2009.00554.x

Ministry of Education. (2013). Ringkasan Eksekutif Pelan Pembangunan Pendidikan Malaysia 20132025 (Pendidikan Prasekolah hingga Lepas Menengah). Bahagian Perancangan Dan Penyelidikan Dasar Pendidikan Kementerian Pelajaran Malaysia. http://www.moe.gov.my/cms/upload_files/articlefile/2013/articlefile_file_003113.pdf Ministry of Education. (2017). Preschool Education(Standard-Based Curriculum and Assessment Document).

Jamil, M. R. M. (2016). Model Kurikulum Latihan SkiVes bagi Program Pengajian Kejuruteraan Pembelajaran berasaskan kerja (WBL) Politeknik Malaysia. University of Malaya.

Muchau, J. W. (2015). Teacher-related factors and errors preschool children make in learning the English language in murang' county schools. 53. http://erepository.uonbi.ac.ke/bitstream/handle/11295/92808/Muchau\%2Cjuliet w_teacherrelated factors and errors preschool children make in learning the English language in murang'a county schools. pdf?sequence=3\&isAllowed=y

Mullen, G. (2017). More Than Words : Using Nursery Rhymes and Songs to Support Domains of Child Development. 42(2), 42-53.

Murray, J., \& Hammons, J. (1995). Delphi: a versatile methodology for conducting qualitative research.

Murray, T. J., Pipino, L. L., \& Van Gigch, J. P. (1985). A pilot study of the fuzzy set modification of Delphi. Human Systems Management, 5(1), 76-80. https://doi.org/10.3233/HSM-1985-5111

National Association for the Education of Young Children. (1998). Learning to Read and Write: Developmentally Appropriate Practices for Young Children. Young Children.

National Association for the Education of Young Children. (2009). Developmentally appropriate Practice in Early Childhood Programs Serving Children from Birth through Age 8. Young Children. 
INTERNATIONAL JOURNAL OF ACADEMIC RESEARCH IN BUSINESS AND SOCIAL SCIENCES

Vol. 10, No. 7, July, 2020, E-ISSN: 2222-6990 @ 2020 HRMARS

Oddo, J. M. (2015). The Importance of Play in the Development of Language Skills. Atlanta Speech School.

Piaget, J. (1959). The language and thought of the child. In M. Gabain \& R. Gabain, Trans.) (3rd ed.). Routledge/Taylor \& Francis Group.

Ragin. (2007). Qualitative Comparative analysis using Fuzzy Sets (fsQCA). In Configurational Comparative Analysis. London: Sage Publication.

Reigado, J., \& Rodrigues, H. (2018). Vocalizations produced in the second year of life in response to speaking and singing. Psychology of Music, 46(5), 626-637. https://doi.org/10.1177/0305735617719335

Rosnaini, M. (2006). Kesediaan Teknologi Maklumat dan Komunikasi Asas dalam Pendidikan Guruguru Sekolah Menengah. Universiti Kebangsaan Malaysia.

Rowe, G., \& Wright, G. (2001). Expert Opinions in Forecasting: The Role of the Delphi Technique. 125-144. https://doi.org/10.1007/978-0-306-47630-3_7

Vygotsky, L. (1986). Thought and language. In A. Kozulin (Ed.), The MIT Press (Vol. 5, Issue 1). The MIT Press. https://doi.org/10.3233/BEN-1992-5106.

Yusof, N. A. A. M. (2019). Pembinaan Model Kandungan Kurikulum Pendidikan Keamanan Berasaskan Multibudaya untuk Kanak-kanak Prasekolah. University Malaya.

Zadeh, L. A. (1965). Fuzzy sets. Information and Control., 8, 338-353. 